\title{
THE IMPACT OF THE INTERNATIONAL CONVENTION \\ ON THE RIGHTS OF PERSONS WITH DISABILITIES \\ ON QATARI DOMESTIC LEGISLATION ${ }^{1}$
}

\author{
RAFAEL DE ASÍS ROIG ${ }^{2}$ \\ MARÍA DEL CARMEN BARRANCO AVILÉS ${ }^{3}$ \\ PATRICIA CUENCA GÓMEZ ${ }^{4}$ \\ PABLO RODRÍGUEZ DEL POZO ${ }^{5}$ \\ KHALID AL ALI ${ }^{6}$
}

\begin{abstract}
The entry into force of the International Convention on the Rights of Persons with Disabilities means that State Parties shall adapt their legislation and regulation to the social model designed in the international text. The present work aims to identify the general challenges faced by Qatar in that task. After presenting the keys to understanding the requirements of the Convention, the paper underlines the necessity of a cultural change in addition to a legal one. In this way, Qatar shares with other State Parties theoretical, legal, social and economic problems. Specifically, the current medical model in Qatar policies should be replaced with the conventional social model. This implies the elimination of discrimination based on disability, the universal accessibility, the legal capacity for persons with disabilities and their right to live independently. A priority is to generate an associative movement around disability.
\end{abstract}

Keywords: Disability in Qatar; Human Rights and Disabilities; International Convention on the Rights of Persons with Disabilities; Social Model of Disability; Accessibility; Legal Capacity.

Summary: I. The International CONVENTION ON THE Rights OF PERSONS With Disabilities. GENERAL GUIDING PRINCIPLES; II. IMPLEMENTING THE CRPD: UNIVERSAL CHALLENGES FOR QATAR III. IMPACT OF THE CONVENTION ON THE QATARI LEGAL SYSTEM; III. 1. The model of disability: medical and rehabilitative III; 2. Universal accessibility; III. 3. Universal legal capacity; IV. CONCLUDING REMARKS.

\footnotetext{
${ }^{1}$ This research was made possible by a NPRP award \# NPRP 7 - 380 - 051 from the Qatar National Research Fund (a member of The Qatar Foundation). The statements made herein are solely the responsibility of the authors.

${ }^{2}$ Universidad Carlos III de Madrid, Spain (rafael.asis@uc3m.es).

${ }^{3}$ Universidad Carlos III de Madrid, Spain (mcarmen.barranco@uc3m.es).

${ }^{4}$ Universidad Carlos III de Madrid, Spain (patricia.cuenca@uc3m.es).

${ }^{5}$ Weill Cornell Medical College in Qatar (prd2002@qatar-med.cornell.edu).

${ }^{6}$ Qatar University (kalali@qu.edu.qa).
} 


\section{INTRODUCTION}

Qatar ratified the United Nations (UN) Convention on the Rights of Persons with Disabilities (CRPD) in May 2008 and is obliged as a signatory nation to implement a number of social and legal measures to become fully compliant. Elsewhere (Rodríguez del Pozo et al. 2016) we have mentioned that this process requires a thorough study of doctrinal problems and public policies, and reform-oriented research that can give us some early clues regarding the general contextual and legal configuration of Qatar concerning the protection of persons with disabilities.

This article presents some results of a legal research aimed at analyzing the consistency between the current Qatari legislation and the mandates of the International Convention of the Rights of Persons with Disabilities as a norm of a higher hierarchy explicitly embraced by Qatar. In this context, only the legal rules are the object of study in this research. This does not mean disregarding the importance of factual issues in the effectiveness of implementing the CRPD through domestic law. This is, though, the first step towards understanding the impact of the Convention on the domestic legislation of Qatar. Once this is understood, the social sciences will need to do further research to determine how the legislation translates into tangible results on the field.

In this paper we will discuss in general terms the main areas in which implementation of the CRPD will affect domestic legislation in Qatar. As we write this paper, the State of Qatar is addressing the September 3, 2015 observations of the Committee on the Rights of Persons with Disabilities, which are based on the progress report submitted by Qatar earlier in the year, and we believe that our work can help both the experts and the stakeholders identify the present and near-future challenges posed by the CRPD that will have an impact on Qatari legislation at large ${ }^{7}$.

We will start by discussing the CRPD's innovative approach to disability and human rights and we will describe some of the common challenges that signatory states have faced when working to implement the Convention, including some secular social preconceptions, some elements of classical legal doctrine that gainsay aspects of the CRPD and financial warnings that could slow down the process of adapting domestic legislation to the mandates of the CRPD. This will help put into context the main focus of our work. In a subsequent section, we will analyze the possible implications of the CRPD for Qatar's legislative framework. We will focus first on the disability model used when determining the legal definition of disability. Secondly, we will analyze how the general guiding principle of universal accessibility is present in Qatari legislation so that we can later discuss how the principle of universal legal capacity contained in the CRPD might best be amalgamated. In this area we have found reasons to be more optimistic than the United Nations committee tasked with following up on the Convention. At every step, we will advance some suggestions aimed at addressing ways in which Qatar might accommodate the main tenets of the CRPD, while understanding

\footnotetext{
${ }^{7}$ UN Committee on the Rights of Persons with Disabilities (CRPD), Concluding Observations in relation to the initial report of Qatar, September 3, 2015, CRPD/C/QAT/CO/1, available at: http://www.refworld.org/docid/55eed9fb4.html. (Last accessed November 1, 2015.)
} 
that the adoption of some basic general steps will help reduce the time and effort required for its further detailed implementation.

\section{The International Convention on the Rights of Persons with Disabilities. General Guiding Principles.}

The Convention on the Rights of Persons with Disabilities was adopted on December 13, 2006 by the General Assembly of the United Nations at the end of a long, participative process that included not only government and international officials but also representatives of associations of persons with disabilities.

Disability was historically outside the concern of United Nations human rights bodies (Quinn and Degener 2002: 20 ff., Lawson 2007, Mégret 2008). This changed in December 2001 when the General Assembly passed Resolution 56/168 creating an Ad Hoc Committee "to consider proposals for a comprehensive and integral international convention to promote and protect the rights and dignity of persons with disabilities based on the holistic approach in the work done in the fields of social development, human rights and non-discrimination and taking into account the recommendations of the Commission on Human Rights and the Commission for Social Development", and inviting the "States, relevant bodies and organizations of the United Nations system, including relevant human rights treaty bodies, the regional commissions, the Special Rapporteur on disability of the Commission for Social Development, as well as intergovernmental and non-governmental organizations with an interest in the matter to make contributions to the work entrusted to the Ad Hoc Committee, based on the practice of the United Nations" 8 .

From the very beginning, thus, the UN General Assembly decided to approach disability based on what we have called elsewhere the social model and placed the future Convention in the framework of the human rights system (Rodríguez del Pozo et. al. 2016). The process culminated in the approval by the United Nations of the International Convention on the Rights of Persons with Disabilities, the first human rights treaty of the $21^{\text {st }}$ century.

The main purpose of the CRPD is "to promote, protect and ensure the full and equal enjoyment of all human rights and fundamental freedoms by all persons with disabilities, and to promote respect for their inherent dignity". This principle is patent throughout the Preamble and the 50 articles of the Convention.

The first nine articles contain general principles about disability and how it should be defined, establishing a general framework for the interpretation of the rest of the text based on the social model of disability. In articles 10 to 30, the Convention uses three different approaches to safeguard the dignity of persons with disabilities. First, it

\footnotetext{
${ }^{8}$ Ad Hoc Committee on a Comprehensive and Integral International Convention on the Protection and Promotion of the Rights and Dignity of Persons with Disabilities, available at http://www.un.org/esa/socdev/enable/rights/adhoccom.htm. (Last accessed November 1, 2015.)
} 
ensures the effectiveness of existing human rights conventions by reformulating and specifying their content, adapting their definitions to the varied situations and experiences of persons with disabilities. Second, it sets out new universal rights such as the right to universal legal capacity, the right to be supported in every decision-making process, the right to universal accessibility, the right to reasonable accommodation and the right to choose a way of life. Third it states a set of specific rights of persons with disabilities.

Since the Convention embraces the philosophy of the social model of disability, disability is understood to be the result of the interaction between individual impairment and social barriers. This is clear in the Convention's definition of disability, in its understanding of the role of the principle of human dignity, in its strategy of nondiscrimination, in the level of importance given to accessibility, in its interpretation of the concept of legal capacity and, finally, in the explicit reaffirmation of an inclusive social model.

Article 3 sets out eight general interpretation and application principles. In this section, we will analyze the five most salient ones starting with those two that we deem particularly important since they govern the contemporary discourse on rights: equal human dignity and non-discrimination.

The principle of equal human dignity is at the heart of the moral foundation of human rights (Peces-Barba 2001, Ansuátegui 2012). The concept of human rights cannot be understood outside this framework. This principle demands the free development of the personality; that every person, on the basis of his or her own autonomy, can choose and implement his or her life plan (Asís 2013). Human dignity, in this context, presupposes an independent living. This principle also presupposes that all human beings have an equal dignity. Equality in terms of dignity thereby becomes another pillar of the Convention. Among the different ways of defining equality (Ribotta 2010), the Convention adopts one of non-discrimination and respect for diversity.

The strategy of the CRPD is to rely on the principle of non-discrimination with regard to all existing rights in order to ensure that such rights can be equally exercised by persons with disabilities. The idea of equality, embedded in the Convention, determines the corresponding obligations of the States Parties to ensure persons with disabilities are able to realize those rights (Palacios 2009). The text clearly establishes the unacceptability of any distinction or exclusion, or any restriction of rights at any time and in any field, on the basis of disability. The concept of non-discrimination focuses on the discriminatory result and not on the intention and covers discrimination of all types (direct, indirect and structural) (Quinn 2007).

Universal accessibility is already contained in the Preamble of the International Convention on the Rights of Persons with Disabilities, highlighting the importance of "enabling persons with disabilities to fully enjoy all human rights and fundamental freedoms". Within the Convention, accessibility is also included in the general 
principles of Article 3, while the whole of Article 9 is dedicated to the issue of accessibility. Throughout the Convention, universal accessibility is justified by taking three other fundamental rights as a reference: living independently, participating in social life and the right to equal opportunity ${ }^{9}$. Full participation in social life is a right contained in the definition of disability and is the basis of many of the rights highlighted by the Convention. However, although accessibility may be achieved through different means, it is important to focus attention on two of them in particular: universal design and reasonable accommodation (Asís 2013: 77, Asís 2007, Barranco et al. 2009: 27-42).

Universal design means "the design of products, environments, programs and services to be usable by all people, to the greatest extent possible, without the need for adaptation or specialized design" (Article 2). Meanwhile, reasonable accommodation refers to measures intended to adjust the environment, goods and services to the specific needs of a person. Reasonable accommodation acquires its full meaning when accessibility cannot be universally granted and thus it becomes an active right intended to remedy this particular situation. For example, it is a matter of universal accessibility to build ramps or install lifts for easy access to a university. It is a matter of reasonable accommodation to install a particular kind of light bulb at some reading desks in the library for those for whom standard lighting would not permit them to read.

An integrated approach to accessibility involves: (i) universal design, which functions as a general principle that is the source of specific duties on the part of the government and the private sector; (ii) accessibility measures, which are required when universal design is not satisfied; (iii) reasonable accommodation, when it has been established that accessibility is not universal, which arises when universal design is not enough to assure accessibility in a particular situation because the features useful for the majority act as barriers when they interact with persons with special personal conditions.

The question of the legal capacity of persons with disabilities was one of the most controversial topics in the negotiations that led to the Convention. Evidence of this is that during one of the sessions, the eighth, the Convention was approved with a footnote to the relevant article that read, "In Arabic, Chinese and Russian, the term 'legal capacity' refers to 'legal capacity for rights', not the 'legal capacity to act"'. Finally, after a complex negotiation process, it was decided to suppress the footnote referred to above. In general terms, the discussion centered on the adoption of two possible approaches: the first, and older of the two, adopted the "model of substitution in the taking of decisions" with its implied distinction between the capacity for rights and the capacity to act, thus perpetuating the condition of guardianship (or the equivalent status in each of the States Parties) as an essential instrument. The other, a really novel view, in accordance with the social model, adopted the "model of assistance in the taking of decisions". This meant that a new legal status would have to be found, the basis of which would be providing support in the taking of decisions instead of substituting the

\footnotetext{
${ }^{9}$ Committee on the Rights of Persons with Disabilities, General Comment No. 2. Article 9: Accessibility (adopted April 11, 2014), CRPD/C/GC/2.
} 
decision-making capacity altogether. The adoption of the assistance model amounts to an authentic paradigm shift in this area, one that will have an important impact on national legislation in countries that currently use the substitution model ${ }^{10}$. We will discuss below the challenges that this new paradigm might pose for Qatar, and the excellent position the country is in to enable its implementation.

Finally, the defense of living independently and the advocacy of nondiscrimination makes the CRPD an instrument that seeks to achieve an inclusive society that respects diversity. Inclusion and respect for diversity, from a human rights approach, relies on four pillars that should structure public life and public ethics, namely, political participation, education, employment and the culture-leisure-sport triad. The Convention thus states inclusive education, inclusive employment and inclusive sport, are mandatory. It must be noted that inclusion is not only the opposite to separation, but that it is also different from mere integration. Inclusion is not always opposed to the construction of special and exceptional circumstances arising from special features, as long as they respect, as much as possible, individual rights and promote diversity.

The implementation of the CRPD has had some immediate repercussions, some of which represent a complete turnaround from the traditional approach towards persons with disabilities. Firstly, the CRPD transformed the way disability is viewed; rather than treating disabled persons as passive receivers of charity, they become active subjects of human rights. In this new paradigm, the social disadvantages suffered by the disabled are not to be eliminated as a result of the goodwill of others or of the State: instead, they should be eliminated because those disadvantages violate their fundamental human rights.

The second impact of the CRPD is that it has given persons with disabilities enormous visibility as a group; a natural consequence of the paradigm shifting from the expectant passivity of receiving charity to the active demands of defending fundamental rights.

Thirdly, the CRPD has had significant repercussions for education at every level. Inside the group of persons with disabilities and those who work on their behalf, the Convention will naturally drive awareness of the CRPD as a legal tool to advance the rights of the disabled. At the societal level, the CRPD promotes the education of citizens on the nature and dimensions of disability. In formal academic education, the CRPD requires that the needs of disabled persons are accounted for in the design of professional qualifications in an array of disciplines, ranging from law to engineering and from architecture and urban planning to political science.

Lastly, but most importantly, given the focus of our study, is the impact of the CRPD on the domestic legislation of signatory states. The ratification and subsequent

\footnotetext{
${ }^{10}$ On this paradigm shift, see Quinn, G. (2009) and Quinn, G. (2010). See also Bariffi, F. (2009) and Cuenca (2011).
} 
putting into effect of the Convention require a revision, and oftentimes a reform, of the internal legislation of the different countries.

\section{IMPLEMENTING THE CRPD: UNIVERSAL CHALLENGES FOR QATAR}

Implementing the Convention and the social model of disability that it postulates is not an easy task for the legal system of any country. Qatar will not be the exception. These challenges are beyond the reach of our study, but they need to be mentioned in order to have a comprehensive view of the work that lies ahead for Qatar and to help place our contribution into the general context of that work.

Implementing the CRPD has posed theoretical and philosophical challenges: challenges stemming from traditional legal doctrine and challenges that are social in nature.

The theoretical challenges have to do with the acceptance of the social model of disability as the new philosophical paradigm, which requires leaving behind the historically assumed link between the social value of the person and his or her capabilities. The social model of disability is frequently viewed as being impossible to implement, while it is sometimes denounced as being limited to physical disability and one that pays little attention to diversity (Asís 2013: 18 ff.). These criticisms observed in other State Parties are most likely to arise in Qatar, and the social actors and stakeholders must be prepared to address them.

Problems related to traditional legal doctrine arise, first, from the consideration of international law as a weak mandate, which calls into question the binding power of international treaties. Legal doctrine will need to be updated to accept that treaties establish true legal standards, which on occasion will have a domestic constitutional dimension (Cuenca 2012: 60-97, Asís 2004). A second problem arises from the assimilation of the rights of persons with disabilities into broader economic, social and cultural rights, in which protection is always loosely defined (Ansuátegui 2010, Barranco 2010). Every effort should be made to ensure that legal doctrine includes the fact that persons with disabilities have individual, civil and political rights as well as economic and social rights, and that they are protected under a uniform human rights statute.

The third legal-doctrinal problem revolves around the notion of capacity. Legal personality has classically depended on capacity, therefore the lack of recognition of capacity for persons with disabilities almost equates to their legal non-existence (Quinn 2009, Asís 2012). The typical response to the capacity of persons with disabilities is the replacement of the will of the disabled with the will of his or her representative. The model of supported or assisted capacity is, in this context, difficult to accommodate into the traditional legal doctrine. As we will see below, Qatar already has made some inroads towards a model of assisted capacity, which will probably make its acceptance much easier than in other countries. 
Social problems have to do with the public perception of disability. The disabled are still considered to be less valid, or even abnormal. Disability is regarded as a misfortune ${ }^{11}$ and in some areas individuals are uncomfortable in the presence of persons with disabilities. The medical-rehabilitative model is still mainstream in most societies where disability is regarded and treated as illness. Ultimately, the social model is not prevalent in the general population, which creates a number of obstacles to implementing the CRPD; from lack of political priority to the fear of governments, from unpopularity to social rejection of measures considered as alien to a particular culture or simply too progressive. Another kind of social problem stems from persons with disabilities, and particularly their families, being fearful that a new way in dealing with disability will decrease their protection mechanisms and put the persons with disabilities, ironically, in a much more disadvantageous position ${ }^{12}$.

An additional social problem comes from the perception among the persons with disabilities and their families that in the context of the CRPD rights play a limited role in relations between private parties. Education is needed to spread an understanding that human rights also include the sphere of private contracts and actually limit the freedom of the parties to include clauses that are incompatible with those rights ${ }^{13}$.

The last group of challenges are of an economic nature. Some fear that adopting the CRPD will have a negative impact on legal certainty, thus negatively impacting private business and economics in general since unpredicted, poorly understood rights may lead to imbalances in the field of legal and economic relations among parties. Others point out that implementing the CRPD is too costly. It should be made clear to the public and to the business sector that the cost of implementation is not excluded from the rights discourse ${ }^{14}$ and that cost considerations could limit changes made as a consequence of the CRPD if it is proven that to do so will have a negative impact on other rights ${ }^{15}$.

Some of the problems highlighted are also present in one form or another in the other States Parties. Additionally, Qatar is immersed in a comprehensive review of its legal and institutional organization. Its strategy is aimed at renewing and developing the country, thereby reinforcing Qatar's commitment to human rights. Nevertheless, reforms are occurring right now, so the architecture of their design and the processes employed to enforce these reforms are still open to input in the light of the CRPD. Furthermore, particular attention must be paid to the situation of certain groups or individuals, like women or migrant workers, in order to avoid multiple or intersectional discrimination, especially in cases where disability is also present. Additionally, Qatar's

\footnotetext{
${ }^{11}$ On the theory of personal tragedy, see Oliver, M. (1996: 32) and Barnes, C. and Mercer, G. (2003:2-3).

12 These preventions and fears are sometimes present in the discussions and comments of States representatives and NGO representatives in the text of the draft available in the Report of the Working Group to the Ad Hoc Committee, A/AC.265/2004/WG/1, available at

http://www.un.org/esa/socdev/enable/rights/ahcwgreportax2.htm. (Last accessed November 9, 2015). See also De Asís (2013: 19ff.)

${ }^{13}$ See, on this last debate, Venegas, M. (2004).

${ }^{14}$ Holmes, S. and Sunstein, C. R. (1999).

${ }^{15}$ De Asís (2013: 145ff.)
} 
presence in the international system of human rights protection is still relatively recent and the State is waiting for the ratification of instruments such as the International Human Rights Covenants of 1966; the Working Group on the Universal Periodic Review shows the intention to ratify these particular covenants in their Report.

\section{IMPACT OF THE CONVENTION ON THE QATARI LEGAL SYSTEM}

The CRPD was ratified by Qatar in 2008. Therefore the CRPD is mandatory for the State. Qatar signed the Optional Protocol allowing for individual complaints (July 9, 2007), but this has not yet been ratified. Qatar submitted its initial report to the Committee on the Rights of Persons with Disabilities in June 2012; the Committee considered this report and published a list of Concluding Observations on September 3, $2015^{16}$.

It is possible to identify, based on the analysis of the legal framework in the light of the CRPD, two kinds of changes to the Qatari legal system that will be necessary: the general and the specific. The former has to do with the legal status and the social perception of disability, while the latter refers to specific reviews of the current legislation. In the following pages we will consider the model of disability and the impact of the guiding principles of universal accessibility and of universal legal capacity, which were explored earlier, to analyze the impact of the CRPD on Qatar's domestic legislation. Some of our observations are supported by the above-mentioned Concluding Observations of the Committee.

\section{III.1. The model of disability: medical and rehabilitative}

A look at Qatari legislation through the CRPD lens highlights two preliminary conclusions that may serve as a working hypothesis related to the disability model and legal rules that support it: the prevalence of the medical model and the invisibility of disability.

The legal framework of Qatar seems to address disability in a medicalrehabilitation-charity model approach. Disability is thus categorized as individuals who present special features and so are outside the range of what is considered normal. The goal in dealing with disability seems to be in trying to prevent it, and, if it occurs, to correct or rectify it as much as possible through domestic or State care for the disabled.

These remarks come from the accepted norm that defines persons with disabilities: Law 2/2004 on the Respect for People with Special Needs, a provision based on special characteristics (special needs) and the importance of rehabilitation. This categorization may turn the treatment of persons with disabilities into a process of segregation by creating special systems and specialized solutions rather than including them in existing social structures such as schools, workplaces and local communities.

\footnotetext{
${ }^{16}$ UN CRPD, Concluding Observations.
} 
This structure does not allow for universal accessibility, although there are many exceptions introduced by different departments and government agencies. The system of incapacitation and guardianship follows the same pattern, as we will see below.

The Committee on the Rights of Persons with Disabilities has made similar observations when noting that Qatari legislation on persons with disabilities "does not reflect the human rights model of disability" and that "there is a heavy focus on creating specialized solutions which lead to segregation" ${ }^{17}$.

The medical model seems to be the most widespread in most societies, even in those that embraced the human rights model long ago. However, in the legal field, the medical model is being superseded, and it is certainly not the model employed by the Convention. Hence the importance of changing this model in Qatari legislation and replacing it with the social and human rights-based model.

The second part of this preliminary observation is that, although there have been significant efforts in promoting the wellbeing of persons with disability in Qatar (Rodríguez del Pozo et al. 2016), disability in itself has not yet received systematic attention from legislation. This phenomenon is called the invisibility of disability, and has been observed in most countries as a consequence of embracing the medical or rehabilitation model. In this sense, the Committee has noted that disability-based discrimination is not explicitly prohibited in the Qatari legal framework ${ }^{18}$, which has made it quite difficult for persons with disabilities to invoke their rights and seek legal remedies, thus remaining invisible as a problem.

Indeed, even though there is a norm for persons with special needs -Law No. 2 of 2004- the definition of disability is not explicit in a number of policy areas. When it is present it is included from the perspective of the medical model. While this is better than no presence and shows Qatar's basic commitment to persons with disabilities, there are practically no references in the fields of television and broadcasting, transport, culture, sports, participation in social, political and cultural life and other legislative areas. The near absence of a direct reference to persons with disabilities in the Qatari constitution is saved by a clear reference when establishing the requirements for access to political bodies and institutions, but its absence is noticed when the supreme law makes reference to equality.

In order to become fully compliant with the CRPD, it would be necessary for disability to be transversely present throughout Qatari legislation and be based on the social and human rights-based model. The Committee's conclusions support this observation. To this end, we will focus on the two requirements most relevant to the development of disability rights in Qatar, in the order they appear in the CRPD: universal accessibility and universal legal capacity.

\footnotetext{
${ }^{17}$ UN CRPD, Concluding Observations, Paragraph 7.

${ }^{18}$ UN CRPD, Concluding Observations, Paragraph 12.
} 


\section{III.2. Universal accessibility}

Universal accessibility is presented as a sine qua non for the equal exercise of rights by all individuals. In this regard, it cannot be considered to be a matter subject to political goodwill, gracious concessions or as a reward for certain individuals or groups.

From the social model perspective, the problem of a lack of accessibility can, thus, no longer be addressed by adopting special measures within a rehabilitation process. Every person, as a member of society, requires accessibility as an essential condition to enable the material enjoyment of his or her rights by obtaining actual provision of services, using public facilities or effectively communicating with others.

There are some areas that directly affect universal accessibility, namely: access to urban spaces (e.g. public places, buildings and facilities, public roads and parks, beaches, lifts, stairs, parking spaces for cars), buildings (e.g. accommodation, private housing, commercial buildings, public buildings), public transport (e.g. buses, taxis, underground, trains, planes, boats); access to devices or technologies intended to support an individual's mobility (e.g. guide dogs, wheelchairs); access to mass media and telecommunications; access to visual arts; the use of alternative forms of communication such as Braille, sign language or easy reading; the use of assistive technologies for communication, signing and educational purposes; access to health and social services, insurance and financial services, leisure and tourism; and access to public administration services and employment.

The accessibility strategy presupposes the realization of universal design, accessibility measures and reasonable accommodation. Our studies have found that the Qatari legal system still needs a general law on disability or specifically on accessibility that establishes the obligation to remove barriers in all the above-mentioned areas. This is necessary for Qatar to assume the mandate of the CRPD regarding the State's responsibility in promoting the material conditions needed for the full enjoyment of rights.

Nevertheless, there are some encouraging, albeit partial, provisions regarding the accessibility to certain facilities. In recent years, particularly since the ratification of the CRPD, a number of interesting initiatives have been launched. The Supreme Council for Family Affairs made available a sign language dictionary, compiled through the Qatar Cultural \& Social Center for [the] Deaf ${ }^{19}$. The Supreme Council for Information and Communication Technology (ictQATAR) issued, in 2011, a National eAccessibility Policy to make ICT more accessible for persons with disabilities ${ }^{20}$. This policy aims at ensuring persons with disabilities have equal access to technology and it

\footnotetext{
${ }^{19}$ Qatar Cultural \& Social Center for [the] Deaf (QCSCD). The Two Parts Arabic Sign Dictionary 2008, available at http://qdeaf.org. (Last accessed, November 11, 2015.)

${ }^{20}$ Supreme Council for Information and Communication Technology (ictQATAR), Qatar's eAccessibility Policy, 2011, available at

http://www.ictqatar.qa/sites/default/files/documents/QATAR's\%20eAccessibility\%20Policy\%20-

\%20Eng.pdf. (Last accessed, November 11, 2015.)
} 
covers a range of e-Accessibility issues including websites, telecommunications services, handsets, ATMs, government services, access to assistive technologies and digital content.

From the CRPD perspective, it would be highly desirable for Qatari legislation to assume the universality of accessibility as a precondition of the exercise of human rights and to aim to secure the full participation of persons with disabilities in all aspects of social life ${ }^{21}$.

\section{III.3. Universal legal capacity}

The Convention approaches the problem of legal capacity in Article 12, which embodies what is known as the "help and support in the taking of decisions model", by stating that "States Parties shall recognize that persons with disabilities enjoy legal capacity on an equal basis with others in all aspects of life." As was apparent from the discussions preceding the final text of the Convention ${ }^{22}$, Article 12 was quite controversial given the legislative modifications that it would impose on the domestic legislation of signatory states. This article represents perhaps the biggest challenge that stems from the CRPD, since it incorporates the capacity to act-that is the capacity to create, modify or terminate legal relations by oneself-into the concept of legal capacity, going beyond the notion of capacity as the capacity to acquire rights.

This novel concept, which represents the abandonment of the "substitution in the taking of decisions" model and its replacement with one of "assistance and support in the taking of decisions", projects its influence across all of the rights granted by the CRPD, and is likely to provoke major waves in the domestic legislation of the State Parties.

The traditional view of legal incapacitation, based on a concept of disability anchored in the medical model, resulted in the absolute limitation of the legal capacity of certain people with physical or mental disabilities who were prevented from carrying out certain acts related to their assets and other matters of civil life (Dhanda 2007, Asís 2012: 5-25). The philosophy that informs the CRPD, inspired by the social model and the principle of non-discrimination, supersedes this view. The traditional model is not consistent with the CRPD requirements.

There is, therefore, a need for new legal instruments based on support for the decision-making model and taking into account particular circumstances on a case-bycase basis, paying special attention to those expressions of the individual's will that either have to do with fundamental rights or with the type of help necessary for the person in his or her specific circumstances.

\footnotetext{
${ }^{21}$ UN CRPD, Concluding Observations, Paragraph 19.

${ }^{22}$ See the Report of the Working Group to the Ad Hoc Committee, A/AC.265/2004/WG/1

http://www.un.org/esa/socdev/enable/documents/ahcwgreport.pdf. (Last accessed November 8, 2015.)
} 
Qatari legislation naturally responds to the pre-CRPD model, and thus allows the deprivation or limitation of the legal capacity of persons on the grounds of disability, supporting the substitution model in the decision-making processes. The Civil Code and Family Code determine that the recognition of full legal capacity depends on full legal age, the age of majority being 18, and on mental competence. In this regard, those who are not considered to be in a sound state of mind can be incapacitated and appointed a guardian.

Law No. 40, 2004, on the Guardianship over Minors Funds provides that "No person above the age of majority who is subject to a habitual state of madness or insanity, or is unconscious, mentally deranged or an imbecile ... shall be allowed to take charge of his own affairs or to administer his estate." In its general provisions the Act defines the meaning of "the insane", "the unconscious", "the idiotic" and "the imbecile" and identifies them as people with mental, intellectual or cognitive disabilities.

Interdiction or incapacitation of a person requires a court decision after verifying their condition through the oral testimony of knowledgeable people or employing other legitimate means of proof. Legally incapacitated persons are subjected to a system of guardianship in which a third party takes care of or represents the person, or both, and administers his or her property in accordance with the provisions of the law. To carry out some proprietary acts of special relevance, the guardian needs judicial authorization.

Mental competence is also considered in Qatari legislation as an essential requirement for the realization of legal acts and the exercise of civil rights including the right to marry and the right to a family life, to give or withdraw free and informed consent to medical care and to access justice.

However, there are some elements in Qatari legislation that are somehow avant la lettre compliant with the CRPD, and could be interpreted as the seed of a new model that might extend throughout the legislation. In effect, the Civil Code, although anchored in the substitution model, allows persons with severe physical and sensory disabilities (particularly deaf and dumb, blind and deaf, or blind and dumb) who "cannot understand the contents or surrounding circumstances of a contract, or cannot effectively communicate his will" the possibility of appointing "a judicial assistant to assist such person as may be necessary in his best interests" (Article 127). This notion could be extended to all fields where assistance in the taking of a decision is required. In any case, this assistance should focus not on the criterion of protecting the individual's best interests but on supporting their expression of will and preferences. This approach, perhaps not easy to implement, would make Qatari legislation truly advanced in implementing the mandates of the CRPD.

At any rate, it is safe to say that assisted capacity is not an alien notion in Qatari law. This could be an advantage in the process of implementation. 
This would require, however, no small effort, since the legislation would come to recognize the legal capacity of all persons with disabilities and would need to establish an assistant system that allows them to make all decisions themselves and exercise, with assistance, their rights in as much as that is possible (Quinn 2010) ${ }^{23}$.

In this area, the Committee on the Rights of Persons with Disabilities has expressed its "deep concern" about the Qatari legislation on legal capacity and has recommended that the country carry out "a review of its legislation with a view to repeal regimes of substituted decision-making and replace them by supported decision-making regimes which uphold the autonomy, will and preferences of persons with disabilities $^{24 "}$.

We believe that this statement is rather pessimistic and perhaps not completely fair. The Qatari Civil Code already contains, for special cases, a possible notion of supported capacity, and would just need to extend the assisted capacity model granted for those special cases to the rest of those that fall under the protection of the CRPD.

\section{CONCLUDING REMARKS}

The CRPD is an innovative text in the treatment of disability in the way it has been crafted with the participation of persons with disabilities, in the philosophy and guiding principles it adopts, and in its legally binding status for the signatory countries as an integral part of the universal international human rights protection system. Its ratification implies for each country the legal mandate to adjust their national legislation and their public policies regarding the treatment of persons with disabilities.

The CRPD redefines disability as the result of an interaction between the particular conditions of the individuals and the environmental, socially constructed barriers that prevent or hinder their participation in social life on an equal basis. The CRPD's ultimate goal is to achieve an equal enjoyment of human rights and freedoms for all.

The CRPD establishes a series of guiding principles, among which equal dignity and non-discrimination are key. In addition, the CRPD adopts the fundamental principles of universal accessibility and universal legal capacity, and the no-lessimportant concepts of inclusion and diversity. These principles can be made operational by adapting rights that were internationally recognized in a general sense for all human beings, taking into account the need to remove barriers to accessibility at large. The CRPD also recognizes new rights that were not previously defined by any international law.

\footnotetext{
${ }^{23}$ On the model of support, see Cuenca, P. (2012).

${ }^{24}$ UN CRPD, Concluding Observations, Paragraphs 23 and 24.
} 
The Convention represents a radical break with historic tradition concerning the consideration and treatment of persons with disabilities. In this new framework, persons with disabilities are no longer passive receivers of charity but rather beneficiaries of enforceable rights. This translates into the need to review and sometimes reinterpret or even reform the domestic legislation of the signatory countries.

Like many other countries, Qatar will face a number of challenges in becoming fully CRPD-compliant. Some of these have to do with theoretical or philosophical issues, others stem from the prevalent legal doctrine, and yet others are social in nature.

Other challenges are more specific. The Qatari legal framework addresses disability from the medical-rehabilitation-charity model. This atomizes the application of the principle of universal accessibility, leaving it to the discretion of different departments and agencies, without a unifying body of rules.

The medical model prevalent to date in Qatar also affects the principle of universal legal capacity, which requires abandoning the so-called substitution model to adopt a model of assistance and support in the making of decisions for all persons with diminished mental abilities. In this point we find that Qatar is quite well positioned to embrace the principle of assisted capacity since it already exists for some specific cases in domestic legislation. This would mean a breakthrough in the region. In this regard, we humbly disagree with the opinion of the UN Committee on the Rights of Persons with Disabilities, which is much less optimistic.

We recognize that full implementation of the CRPD may require a cultural change, and that such a change should not rely exclusively on legislative amendments, but also on the awareness of the public and the sensitivity of those applying the legislation.

\section{REFERENCES}

Ansuátegui Roig, F. J. (2010). “Argumentos para una teoría de los derechos sociales”, Ribotta, S. and Rossetti, A., (eds), Los derechos sociales en el siglo XXI. Un desafío clave para el Derecho y la Justicia, Dykinson, Madrid, pp. 41-62.

Ansuátegui Roig, F. J. (2012). “Diritti fondamentali e dignitáumana”, Ragione Pratica, no. 38, June 2012, pp. 11-24.

Asís , R. de (2012). “Sobre la capacidad” en Bariffi, F. and Palacios, A., (coords), Capacidad jurídica, discapacidad y derechos humanos. Una revisión desde la Convención Internacional sobre los derechos de las personas con discapacidad, Ediar, Buenos Aires, pp. 13-29

Asís, R. de (2004). "Sobre cómo interpretar la Constitución y sobre quién debe ser su intérprete”, in Peces-Barba, G. and Ramiro, M. A. (coords.), La Constitución a examen. Un estudio académico 25 años después, Dykinson, Madrid, pp. 285-302. 
Asís, R. de (2007). "Sobre el concepto de accesibilidad universal”, in Ruiz, B. and Utray, F. (coords.), Accesibilidad a los medios audiovisuales para personas con discapacidad, Real Patronato sobre Discapacidad, Madrid, pp. 17-24.

Asís, R. de (2013). Sobre discapacidad y derechos, Dykinson, Madrid.

Asís, R. de et al. (2012). "Capacidad jurídica y discapacidad. Propuestas para la adaptación normativa del Ordenamiento Jurídico Español al artículo 12 de la Convención Internacional sobre los Derechos de las Personas con Discapacidad”, Informe "El tiempo de los derecho", no. 23, pp. 5-25, available at http://earchivo.uc3m.es/bitstream/handle/10016/14183/informe_td_23.pdf?sequence=1. (Last accessed June 1, 2015).

Bariffi, F. (2009). “Capacidad jurídica y capacidad de obrar de las personas con discapacidad a la luz de la Convención de la ONU”, in Pérez Bueno and Sastre, Hacia un derecho de la discapacidad, pp. 353-390.

Barnes, C. and Mercer, G. (2003). Disability, Polity Press, Cambridge.

Barranco, M. C. (2010). "Exigibilidad de los derechos sociales y democracia”, in Ribotta, S and Rossetti, A. (eds.), Los derechos sociales en el siglo XXI. Un desafío clave para el Derecho y la Justicia. Dykinson, Madrid, pp. 149-172.

Barranco, M. C. et al. (2009). La accesibilidad universal en los medios audiovisuales de comunicación, Icono, Madrid 2009.

Cuenca, P. (2011). “La capacidad jurídica de las personas con discapacidad”, Derechos y libertades, no. 24, 2011, pp. 221-257

Cuenca, P. (2012). "El sistema de apoyo en la toma de decisiones desde la Convención Internacional sobre los Derechos de las Personas con Discapacidad: principios generales, aspectos centrales e implementación en la legislación española”, Revista electrónica del Departamento de Derecho de la Universidad de La Rioja, REDUR, no. 10, 2012, pp. 61-94.

Cuenca, P. (2012). Los derechos fundamentales de las personas con discapacidad. Un análisis a la luz de la Convención de la ONU, Cuadernos de la Cátedra Democracia y Derechos Humanos, Universidad de Alcalá-Defensor del Pueblo, Madrid.

Dhanda, A. (2007). "Legal capacity in the Disability Rights Convention: stranglehold of the past or lodestar from the future?”, Syracuse Journal of International Law and Commerce, vol. 34, 2006-2007, pp. 438-456.

Holmes, S. and Sunstein, C. R. (1999). The Cost of Rights. Why Liberty Depends on Taxes, W. W. Norton, New York

Lawson, A. (2007). "The United Nations Convention on the Rights of Persons with Disabilities: new era or false dawn?”, Syracuse Journal of International Law and Commerce, no. 34, 2007, pp. 563-619 
Mégret, F. (2008). "The Disabilities Convention: human rights of persons with disabilities or disability rights?”, Human Rights Quartely, no. 30, 2008, pp. 494-516. DOI: https://doi.org/10.1353/hrq.0.0000

Oliver, M. (1996). Understanding Disability: From Theory to Practice, Macmillan, London. DOI: https://doi.org/10.1007/978-1-349-24269-6

Palacios, A. (2009). "La progresiva recepción del modelo social de discapacidad en la legislación española”, in Pérez Bueno, L. C. (dir.) and Sastre, A. (coord.), Hacia un derecho de la discapacidad, estudios en homenaje a Rafael de Lorenzo, Thomson Reuters Aranzadi, Pamplona, pp. 77-114.

Peces-Barba, G. (2001). La dignidad de la persona desde la filosofía del derecho, Dykinson, Madrid.

Quinn, G (2009). “An ideas paper on legal capacity” in Disability, European Foundation Centre, Brussels, available at

http://www.inclusionireland.ie/sites/default/files/attach/basicpage/846/anideaspaperbygerardquinnjune2009.pdf (Last accessed May 11, 2016)

Quinn, G. (2007). "Disability discrimination law in the European Union”, in Meenan, H. (ed.), Equality Law for an Enlarged Europe: towards a Greater Understanding of the Article 13 Directives, Cambridge University Press, Cambridge, pp. 231-277. DOI: https://doi.org/10.1017/CBO9780511493898.009

Quinn, G. (2010). "Personhood \& legal capacity perspectives on the paradigm shift of Article 12 CRPD”, HPOD Conference, Harvard Law School, February 20, 2010, available at http://www.nuigalway.ie/cdlp/documents/publications/Harvard Legal Capacity gq draft 2.doc (Last accessed May 11, 2016).

Quinn, G. and Degener, T. (eds) (2002). Human Rights and Disability: the Current Use and Future Potential of United Nations Human Rights Instruments in the Context of Disability, Office of the United Nations High Commissioner for Human Rights, United Nations, Geneva.

Ribotta, S. (2010). Las desigualdades económicas en las teorías de la justicia, Centro de Estudios Políticos y Constitucionales, Madrid.

Rodríguez del Pozo P., Barranco-Avilés MC., Al-Ali K., de Asís R. (2016). "Implementing the International Convention on the Rights of Persons with Disabilities in Qatar: From Charity to Human Rights”, Journal of Local and Global Health Perspectives, In Press

Venegas, María (2004). Derechos fundamentales y derecho privado. Los derechos fundamentales en las relaciones entre particulares y el principio de autonomía privada, Marcial Pons, Barcelona. 